\title{
МОТИВИ УЧАСТІ ІНДИВІДІВ В ПРОТЕСТНИХ ПОДІЯХ МАЙДАНУ 2013-2014 РОКІВ
}

\author{
А. А. Прохорова \\ Національний Університет Києво-Могилянська Академія, \\ вул. Г. Сковороди, 2, м. Київ, 04655, Україна, \\ anna_prokhorova@ukr.net
}

\begin{abstract}
Стаття присвячена дослідженню мотиваційного компоненту фреймінгу протестних подій на київському Майдані 2013-2014 років. Проаналізовано пул з 300 глибинних інтерв’ю, зібраних в перші півроку після означених подій. Виділено широкий спектр мотивів, що спонукали індивідів приєднатись до Майдану. Проаналізовано характер мотивів, тенденції змін основних стимулів до участі в протесті в залежності від динаміки подій на Майдані та ролей, які індивіди виконували під час революції Гідності.

Ключові слова: Майдан, мотивація, фреймінг, глибинні інтерв'ю.
\end{abstract}

Революція Гідності, що відбулась на київському Майдані взимку 2013-2014 років - важлива частина новітньої історії України. Але політичні події після Майдану розвивались так динамічно і стрімко, що суспільна увага швидко переключилась на анексію Криму та початок військових дій в Донецькій та Луганських областях. Видається, що феномен Майдану так і не був достатньо проаналізований і відрефлексований. Особливо це стосується соціологічних інтерпретацій протесту, аналізу його символічних, соціокультурних компонентів - найбільш цікавого для соціолога аспекту аналізу соціального руху.

Аналіз фреймів (фремінгу) - підхід до розгляду соціальних рухів, запропонований дослідниками Девідом Сноу та Робертом Бенфордом в кінці 1980-х років, що дозволяє дослідити символічні компоненти протесту. Термін «фрейм» був запозичений з робіт Ірвіна Гофмана - автора драматургічного підходу в соціології, який розглядав фрейми як соціально конструйовані значення або схеми інтерпретації соціальної реальності, що дозволяють виокремлювати, сприймати, ідентифікувати та позначати конструкти [5; 10-11, 21]. Девід Сноу та Роберт Бенфорд, базуючись на ідеях Гофмана, констатували, що при аналізі соціальних рухів дослідники не звертають достатньої увагу на те, що суспільні невдоволення виникають саме через відмінні інтерпретації [6; 465-467]. А, отже, дослідження інтерпретацій учасників соціальних рухів соціокультурного контексту дозволить краще зрозуміти причини, характер та перебіг протестів. Крім того, Сноу та Бренфорд критикують прихильників психофункціональних підходів та теорії мобілізації ресурсів - основних парадигм аналізу суспільних рухів - у тому, що вони розглядають участь у протестах і революціях як статичний параметр і не приділяють

(C) Прохорова А. А., 2017 
уваги процесу що пов’язує появу невдоволення у певного індивіда з його рішенням брати участь в протесті. [6; 465-467].

Отже, аналіз фреймів соціального протесту дозволяє зафіксувати процес присвоєння значень, надання інтерпретації ситуаціям і подіям, що формують незадоволення, конфлікт та протестні настрої [4; 74]. Сноу та Бренфорд виділяють 3 компоненти фреймінгу: діагностичний (інтерпретація певної події, чи певного аспекту соціального життя, як проблемного та такого, що потребує змін), прогностичного (запропоноване вирішення цієї проблеми), мотиваційного (обгрунтування стимулів до колективної діiі) [7; 199-204]. Для цієї статті зосередимось на мотиваційному компоненті фреймінгу, розглянувши мотиви до участі в подіях Майдану.

Складно збагнути як один і той самий протест зміг об'єднати правих радикалів та лівих інтелектуалів; тих, хто цікавився політикою і тих, хто до Майдану навіть не знав про підписання угоди про Асоціацію між Україною та Європейським Союзом; тих, хто прагнув в Свропу і тих, хто хотів відроджувати традиційні українські цінності; тих, хто до кінця був за мирний протест, тих, хто радикалізувався поступово і тих, хто 3 перших днів віддавав перевагу силовому сценарію вирішення конфлікту; тощо. У людей Майдану були дуже різні мотиви і цілі виходу на протест. Найбільш цікаво, 3 соціологічної точки зору, дослідити саме індивідуальні мотиви, що спонукали людей до активних дій.

Дані, зібрані Київським Міжнародним Інститутом Соціології та Фондом «Демократичні ініціативи » ім. Ілька Кучеріва демонструють зміни в настроях майданівців в цілому та в їхніх мотиваціях до участі в протесті зокрема [2; 1]. Базуючись на цих даних соціологи ввели специфічні терміни «Майдан-мітинг», «Майдан-табір» та «Майдан-січ» [3], які надзвичайно влучно відображають ключові трансформації характеру протесту та протестних настроїв. Дослідники з'ясували, що найбільше протестувальників спонукали долучитись до протесту такі чинники як: жорстокі дії влади проти мітингувальників (61,3-69,6 \% відповідей респондентів в різні періоди перебігу Майдану), відмова Віктора Януковича від підписання Угоди про асоціацію з Свропейським Союзом (40-53,5 \% відповідей), прагнення змінити життя в Україні (36,2Э51,1 \% відповідей) та прагнення до зміни влади $(38,9-45,6$ \% відповідей). Примітно, що перші двачинники 3 плином часу втрачали свою значимість (хоча жорстокі репресії проти учасників протесту лишились основним стимулом до дій впродовж усього Майдану), а другі два, навпаки, іiі набували (прагнення до змін в Україні в лютневому опитуванні - другий по значимості мотив до участі в протесті). Важливими стимулами також виявились: згортання демократії, загроза диктатури та небезпека (13,7-17,5), що Україна вступатиме у Митний Союз і взагалі поверне до Росії $(14,4-20,0)$. Останній мотив відчутно зріс з кінця грудня до початку лютого - 3 14,4 \% до 20 \% відповідей респондентів. Менш характерним для протестувальників був мотив помсти, однак, кількість людей, які прагнули помститися владі, з початку грудня до початку лютого збільшилась майжевдвічі - 3 5,2 \% до 9,8 \% відповідей опитаних [2; 1$]$.

Наведені вище дані відображають загальний кількісний розподіл мотивів, що спонукали учасників Майдану долучитись до подій. Проте, навіть найкраще репрезентативне опитування не може відобразити весь спектр можливих варіацій певного явища, 
чи події, весь спектр думок людей. В такому випадку доцільно також поглянути на результати якісного дослідження. Глибинні інтерв’ю з учасниками Майдану дозволяють виявити ті когнітивні конструкти та інтерпретації, які лежать в основі мотиваційного компоненту фреймінгу протестного руху. Аналіз глибинних інтерв'ю дасть змогу не лише продемонструвати ширший спектр мотивів, які спонукали учасників Майдану до колективних дій, а й коректніше інтерпретувати ці мотиви. Адже в одному варіанті відповіді на питання кількісного опитування можуть міститись зовсім різні думки респондентів.

Отже, метою цієї статті є аналіз мотивів учасників протестних подій Майдану 2013-2014 років на якісному емпіричному матеріалі.

Дослідження проведене на матеріалі проекту «Майдан. Свідчення», організатори якого 3 кінця лютого по кінець липня 2014 року зробили близько 300 глибинних інтерв’ю 3 різними учасниками Майдану. Респонденти для розмови добирались методом «снігової кулі» 3 елементами методу «максимальної варіації». Детальніше про методологію проекту - в статті «Методологічні особливості дослідження особистих свідчень учасників Майдану 2013-2014 років методом напівструктурованого інтерв'ю» [4].

Переходячи до аналізу, слід зазначити, що мотиви респондентів до участі в протесті змінювались відповідно до зміни контексту подій. Простежимо мотиви участі респондентів починаючи від перших днів листопаду.

Першим стимулом, який необхідно назвати $є$ прагнення продемонструвати власну позицію щодо необхідності підписання Угоди про асоціацію між Україною та СС: «для мене це спочатку був як би вияв громадської активності, непокори, до яких ти, якщо працюєш в громадському секторі, звичний» (3). I, пов'язаний з цим, стимул - бажання змусити владу під моральним тиском з боку громадян таки підписати Угоду (42).

Багато респондентів, які виходили на Майдан в період з 21 по 29 листопада, говорили, що виходять за відновлення політичного курсу України в бік Європи, за Євроінтеграцію, за Європейські цінності. Проте, за свідченням одного з опитаних, ці гасла люди інтерпретували по-різному, і під цими загальними мотивами, часто малось на увазі щось інше, більш конкретне:

«Прийшов я на Майдан і почав розпитуватися людей, взагалі, якого біса вони туди вийшли, що вони мають на увазі під цією євроінтеграцією, що вони очікують від цих протестів і тому подібне. Ну і ще через 5-10 хвилин такої маєвтики люди доходили зазвичай до того, що вони вийшли через якісь соціально-економічні проблеми і що вони таким чином мають надію, що їх можна якось розв'язати...» (177)

I дійсно, серед тих, хто вийшов на Майдан за Євроінтеграцію були і ті, хто хотіли такого рівня життя, як в Європі (інтерв’ю 29), і ті, хто прагнули європейської поваги до прав і свобод громадян, зокрема, до права вибору (інтерв'ю 77), i ті, хто просто бажали їздити в країни Європи без віз (інтерв’ю 19, 29).

Той самий респондент, який розпитував людей про їхні мотиви долучитись до протесту, звернув увагу на те, що багато з тих, хто долучився до мітингів в підтримку підписання угоди про євроінтеграцію, тієї угоди просто не читали і не знали, про що в ній ідеться: «від трьох людей я щуось більш-менш внятне $і$ конкретне почув, $a$ спілкувався, може, з сотнею чи щуось у ц̧ьому стилі. Ну, всі ијі, вони, коротше ман- 
тру повторювали, щзо от Свропа, иче ж так круто, курс на Європу нам всі проблеми повирішує» (177). Але в інших свідченнях є згадки про те, що, опинившись так чи інакше на Майдані, людина починала цікавитись політикою, слідкувати за новинами і розбиратись в суті конфлікту: «После я прочитал в интернете часть ассоциации, решил разобраться, зачем это нам нужно, понял, что это правильное русло, куда нужно идти, и уже с этого времени выходил на майдан за идею» (298).

Ще одна група мотивів, що підштовхнули людей до протесту, пов'язана 3 побоюваннями того, що альтернативою призупинення євроінтеграції стане політичний рух в бік Росії: «...насправді до сих пір Україна головною своєю задачею ставить відхід від впливу Москви. Відхід максимальний, тобто, в протилежний бік. Для того, щзоби просто не залишатися в рабстві, скажем так» (50); «нездорова позиція - прагнути до минулого, та ще й до гіршого. I Росія як напрямок розвитку, щзоб у нас все стало так, як в Росії》 (29).

Хоча загальний дискурс протесту до 30 листопада не містив закликів до зміни влади, деякі учасники вже говорили, що тогочасна влада не може гарантувати дотримання політичного курсу, спрямованого на євроінтеграцію, а відтак, пропонували боротися за зміну влади: «Стало зрозуміло, щуо асоціація з $С С$ з Януковичем неможлива і ніякий розвиток держави з Януковичем, в принџипі, неможливий. Його, абсолютно однозначно, треба було скидати і заміняти владою, яка ц̧ю асоціацію підтримає» (11).

На перших етапах багато людей виходили на заклик політиків. 3 перебігом подій, цей стимул втрачав свою масовість, проте залишався актуальним для частини населення: «Яценюк сказав, щуо «куля в лоб», але треба всім вийти. Вже не збирався виходить, але так подумав, щчо якщо вже кажуть, то вийшов» (5).

Люди долучались до протесту з цікавості, з солідарності з близькими та друзями: «Раз там наш сын, мы должны быть тоже» (69). Так вийшло багато студентів спільно з друзями та колегами: «позвонил мой староста, други сказал, что сейчас собирается митинг, я тогда не интересовался политикой. вначале из любопьтства. Мы просто стояли, я не был радикально настроенный, чисто был интерес» (298). Більше того, людям було важливо, що ці події вони можуть розділити з близькими. Зустріч на Майдані стала ще одним приводом зустрітись в родинному колі чи колі друзів: «Mu завжди своєю родиною ходили, з батьком, з мамою, з сестрою, з ї̈ чоловіком, тобто ми завжди так родиною підтримували ияю ідею» (140).

Як не дивно, вже на першому етапі - етапі Свромайдану, були такі люди, які вийшли у спротив владі й, навіть, у спротив насиллю. «Вийшов з другом, той сказав, щзо б'ють - вдягли екіпіровку, пішли штовхатись» (299) (йдеться про «штовханину» 3 правоохоронцями біля будівлі Кабінету Міністрів 24 листопада 2013 року).

Євроінтеграція як стимул вийти на протест була далеко не для всіх. Представники як лівих, так і правих поглядів, цієї ідеї не розділяли в повній мірі, але трансформували по-своєму: «мій плакат був якраз «В Свропу без ксенофобї» ... наступне гасло для мене дуже важливо, ие «проти полічейської держави», навіть у нас був такий великий транспарант, банер такий... в нас має бути свобода мирних зібрань, свобода вираження власних поглядів» (77).

Респондент, який був на Майдані з 21 листопада, але через робоче відрядження пропустив тиждень, на який випали дні 29 листопада - 1 грудня, так відповів на за- 
питання інтерв'юера щодо того, чи була різниця в настроях на Майдані до та після відрядження респондента: «Дуже серйозна різничя. Ми виходили за політичний вибір країни. А коли я повернувся, це був рух проти насильства та вимога покарати тих, хто пролив кров на Майдані. Дуже серйозна різниця, бо тут ми бачили, щзо долучилися абсолютно всі. І було дивно бачити, наскільки людям легко знайти спільну мову» (42).

Для більшості людей після 29 листопада основними стимулами стали: за дітей, проти побиття мирних громадян, проти насилля: «Це було настільки все дико, скажемо. Настільки неадекватна була реакиія силових структур на цุих дітей, щуо просто миритися з цим було неможливо» (50); "...ие вже ясно Свропа Свропою, але коли стались події ночі з 29-го на 30-те, коли особисто моӥх знайомих, з якими я вчився в одному університеті, пив пиво в одному університеті побили, я не міг литатись осторонь. Вже була мета приїзду - цим мітингом показати, щзо ми не згодні з такою політикою тодішньої влади» (19); «Ну людей бьют, наших бьют. Жалко стало» (26). Багато респондентів ототожнювали людей, які були вночі біля Стели на київському Майдані Незалежності з самими собою, з власними дітьми, говорили, що виходили саме заради власних дітей і їхнього майбутнього в нашій державі: «А я чисто случайно, значит, телевизор посмотрел, увидел, как наших детей избили... Это было ужасно! Это же дети! Там могли быть и мои и ваши... И поэтому поднялись, приехали сюда... За своих детей...» (31).

3 цього моменту стимулами для прояву своєї громадянської позиції стали такі чинники, як: безкарність винних, свавілля влади, недотримання владою прав громадян; люди вийшли за відставку президента, за відставку влади, проти надмірного застосування сили правоохоронцями, проти беззаконня суддів, тощо, і ці чинники 3 плином часу набували більшої значимості для учасників протестних подій: «за те, щуоб не спаплюжили права українців» (24); «Всі розуміли одне: ми хочемо, щоб відповідні люди були притягнуті до відповідальності, і щзо Янукович має піти» (3); «...от реально, вперше я свідомо вийшла після того, шьо відбулося вночі. Перед тим я, напевно, ходила, може, з иікавості» (20); «щуоб все змінилось в намій крайні, дуже підтримую люстрацію, докорінно» (40).

Однак, і тема підписання угоди про євроінтеграцію залишалась важливою для частини протестувальників: «И послеразгона студентов я уже зашел в такую жесткую оппозициию к этой власти, ну и подумал просто, что не уйду, пока не будет подписана Ассоцииацฺия» (297)

Мотивом для частини людей після 30 листопаду стала помста, про це вже частково йшлося вище: «натовп був такий, з високим градусом... вони хотіли щзось зробити, когось розірвати, звісно. Я туди йшов, тому щзо в мене був такий самий настрій... Я хотів чогось правильного і всі ми хотіли, мабуть» (70); «после этого выходили не за Европу, а против системы Януковича, выходили против Януковича, ментов, было желание просто отомстить... У меня была идея отомстить милиции» (298).

Ще одна група мотивів пов'язана з бажанням допомогти тим, хто на Майдані живе весь час, або підтримати тих, хто бере активну участь в сутичках з правоохоронцями: «Я бачила дуже зблизька иุе протистояння, більш пізні місяџі Майдану. Це дуже страшно було. Я, наприклад, не здатна на иее, хіба щзо на мене б нападали безпосередньо. Але те, 
щуо бути присутнім і те, щчо показувати, щчо нам абсолютно не страшно...» (50); «кроме тех чувств, которые чувствовали все, или больиинство людей в городе, таких чувств как солидарность, желание помочь, ничего более у меня не было» (69). Особливо такі мотиви характерні були для киян, які, як правило, не перебували на Майдані весь час, а навідувались $з$ певною регулярністю, або в складні моменти. Відтак, цікавим феноменом київського Майдану і, відповідно, мотивом до участі киян в протестних подіях стало почуття гостинності по відношенню до гостей з інших міст: «Те киевляне, которые понимали, что сами стоять на Майдене не могут, поддерживали тех, кто стоял там за них. Кто одежду собирал, кто по дороге на Майдан покупал воды... Весь Киев, так или иначе, сопереживал, сочувствовал и участвовал» (155); «Мы принимали у себя людей со Львова, с других городов, с Харькова у нас люди ночевали, которые были на Майдане. Мы всегда гостеприимно всех у себя размещали, кто приезжал на Майдан» (199).

Подібним до бажання допомогти є бажання захистити тих, хто віддавав Майдану свій час, здоров’я та сили: «ті, хто там жили, а ви уявіть собі, там же не тільки чоловіки, там жінки, і там же ці підлітки, ви знаєте, які у нас підлітки. Їх треба захищати» (50). I так само аби захистити люди виходили на чергування біля лікарень в періоди, коли на постраждалих з Майдану полювали правоохоронці. Так утворилась ініціатива «Варта в лікарні»: «Щоб були постійно намі люди в лікарні, які чергують, які нам повідомляють, якщз приїхала мілічія. Або якщо когось привезли, щоб знать яке прізвище. От, щуоб люди не пропадали безвісті» (58). Тим самим мотивом - бажання захистити, керувались і учасники «Громадської варти» або «Самооборони мікрорайонів», які виходили патрулювати місто в ночі, аби уберегти населення від нападів «тітушок» та загалом від злочинців. Особливо актуальним це було в період, коли міліція зникла з вулиць Києва (інтерв'ю 21).

На більш пізніх етапах, важливими стають психологічні мотиви участі в діях Майдану. Так, коли в місті перебували бандитські угрупування «тітушки», траплялись випадки побиття, викрадення активістів співробітниками правоохоронних органів, респонденти зізнавались, що найбільш безпечно почували себе саме на Майдані: «страшно було вдома ночувати, не знали, якими дорогами ходити, друзі не знали, де машину на ніч лишати з франківськими номерами» (29). Крім того, респонденти неодноразово зазначали, що в найскладніші дні страх, відчай і зневіра сильніше відчувались вдома перед екраном комп'ютера або телевізора, а на Майдані легше було пережити ту чи іншу подію поряд людьми: «Коли ти далеко від Майдану, подій, то відчуваєш тривогу, а коли там, то заряджаєшся енергією. На майдані бачив тих людей, які готові відстоювати свої права до останнього, і відчуваєш, щзо нема чого боятися» (18).

Так само в часи найбільших загострень конфлікту, на перед виходив мотив, який полягав у тому, що активісти вже зайшли надто далеко і за умов поразки Майдану, їм не буде життя в цій країні. Тому, єдиний шанс - перемогти: «Або режим поневолить народ, будуть репресї, студентів повиключають з університетів, котрі піднімали протести, багато людей, хто виступав, могли опинитись у в 'язниці, або народ завалить той режим» (18); "Я розумію, щуо насправді, якщо зараз оцю всі масу, щуо там стоять, загребуть, то в Украӥні в найближчі 10 років вже нічого не буде. Це реально цчих 5 \% сили, щчо завжди будуть пхати людей вперед» (3). 
Поряд з раціональними мотивами, фігурують такі, що базуються на емоціях. Серед них, мотив «якщо не я, то хто?»: «Якось воно дуже лячно, але ти розумієи, що ти не маєш іншого виходу і окрім тебе більш того ніхто не зробить» (3).

Відчутне місце за свідченнями респондентів, займають також мотиви участі в протесті з моральних причин, через власне сумління - «не міг не бути»: «якщо ми не підем, то себе поважать не будем. Ну і пішли» (27). Так дівчина, яка під час подій Майдану лікувалась від онкологічної хвороби, говорила, що не могла не допомагати хоч якимсь чином, називала цю необхідність власною психологічною потребою (інтерв'ю 26).

I, нарешті, необхідно виділити такий мотив участі в подіях Майдану, як провина. Він особливо характерний для тих, хто не брав участі у фізичному протистоянні, а допомагав речами, грошима, медикаментами, волонтерською роботою. Респонденти підкреслюють, що особливо після загострень протистоянь на Майдан йшли сотні людей з величезними пакетами з усім необхідним (інтерв'ю 19, 20).

Необхідно підкреслити, що кожна акція, яка була так чи інакше дотична до Майдану, окрім загальних ідей Майдану, мала на меті власні локальні цілі. Так, наприклад, лежачий протест під Генеральною прокуратурою було організовано активістами партії «Демократичний альянс» на вимогу звільнити заарештованих за підозрою в організації заворушень біля Адміністрації президента 1 грудня 2013 р. А під час захоплення Міністерства освіти, студентські активісти висували вимогу щодо зміни керівництва Міносвіти (інтерв'ю 177) в період Майдану. Однак охопити всі акції, страйки та протести, що були дотичні до подій Майдану не дозволить обраний емпіричний матеріал, тож в фокусі дослідження залишаться тільки мотиви учасників основних подій того протесту, які відбувались на Майдані Незалежності в Києві та прилеглих вулицях.

Таким чином, в цій статті на широкому емпіричному матеріалі проаналізований мотиваційний компонент фреймінгу протестних подій Майдану 20013-2014 років. Особисті свідчення учасників Майдану, зібрані методом глибинного інтерв'ю, дозволяють виділити ширший спектр мотивів участі активістів у протестних подіях, також, коректніше інтерпретувати їхнє розуміння власних мотивів.

Мотивації респондентів до участі в подіях на Майдані на пряму залежать від подій Майдану. Зміна інтерпретацій власних мотивів до участі в протестній активності відбувається синхронно з основними трансформаціями фреймінгу протесту. Мотиви були відмінними не лише у різних людей в залежності від етапу Майданја якому вони вирішили долучитися до подій. Одна й та сама людина по-різному окреслює причини власних рішень щодо участі в подіях на Майдані на різних етапах.

Крім того, мотиви участі в подіях Майдану різняться в залежності від ролей учасників. Особливо такі відмінності відчутні в період силових протистоянь між мітингувальниками та правоохоронцями: мотиви тих, хто перебуває безпосередньо на Майдані можуть відрізнятись від мотивів тих, хто бере участь в організації життєдіяльності Майдану або допомозі постраждалим. Якщо в першому випадку, це можуть бути мотиви «якщо не я, то хто» або мотив помсти, то в другому, наприклад - мотив провини.

3 аналізу видно, що на початку протесту, мотиви участі активістів були більш конкретними і локальними. Люди виходили проти зовнішньої політики країни, за покарання винних у побитті мітингувальників тощо. Тоді, як з плином часу та із загостренням 
подій, респонденти частіше називають моральні та психологічні мотиви участі в подіях Майдану: сумління, провина, бажання допомогти тощо.

В подальших дослідженнях Майдану з точки зору символічної, соціокультурної інтерпретації, має сенс дослідити інші компоненти фреймінгу Майдану як соціального руху та окреслити основні соціальні феномени, що стали символами Майдану.

\section{СПИСОК ВИКОРИСТАНОЇ ЛІТЕРАТУРИ}

1. Від Майдану-табору до Майдану-січі: що змінилося? [Електронний ресурс] http://dif. org.ua/article/vid-maydanu-taboru-do-maydanu-sichi-shcho-zminilosya. - Назва з екрана.

2. Майдан-мітинг і Майдан-табір: схоже і відмінне [Електронний ресурс] http://dif.org. ua/article/maydan-miting-i-maydan-tabir-skhozhe-i-vidminne. - Назва з екрана.

3. Паниотто В. Евромайдан внутри и снаружи: результаты социологических исследований / Владимир Паниотто // Феномен майдану в українському суспільстві: соціологічні інтерпретації. Матеріали Міжнародних соціологічних читань пам'яті Н. В. Паніної / За наук. ред. С. І. Головахи і О. Г. Стегнія. - Київ : Інститут соціології НАН України, 2015. C. 15-32.

4. Прохорова А. А. Методологічні особливості дослідження особистих свідчень учасників Майдану 2013-2014 років методом напівструктурованого інтерв'ю / А. А. Прохорова // Наукові записки НаУКМА. - 2017. - Т. 200 Соціологічні науки /здано до друку/.

5. Della Porta D. Social movements : an introduction / Donatella della Porta, Mario Diani. Oxford Blackwell Publishing, 2006, 2nd ed. - 345 p.

6. Goffman E. Frame analysis : An essay on the organization of experience /Erving Goffman. Northeastern University Press, 1986. - 586 p.

7. Snow D. Frame Alignment Processes, Micromobilization, and Movement Participation / David A. Snow, E. Burke Rochford, Jr., Steven K. Worden, Robert D. Benford // American Sociological Review. - 1986. Vol. 51, No. 4. - P. 464-481.

8. Snow D. Ideology, frame resonance, and participant mobilization / David A. Snow, Robert D. Benford // International social movement research. - 1988. Vol. 1, No. 1. - P. 197-217.

\section{REFERENCES}

1. Della Porta D., Diani M. Social movements: an introduction / D. della Porta, M. Diani. Oxford: Blackwell Publishing. 2006.

2. Goffman E. Frame analysis: An essay on the organization of experience /E. Goffman. Boston: Northeastern University Press. 1986.

3. Majdan-mitynh i Majdan-tabir: skhozhe i vidminne [Maidan-rally and Maidan-camp: similar and different] http://dif.org.ua/article/maydan-miting-i-maydan-tabir-skhozhe-ividminne [in Ukrainian].

4. Paniotto V. Evromaidan vnutri i snaruzhi: rezul'taty sotsiologicheskikh issledovanii [Euromaidan inside and outside: results of the sociological research] / V. Paniotto // Fenomen majdanu v ukrains'komu suspil'stvi: sotsiolohichni interpretatsii. Materialy Mizhnarodnykh sotsiolohichnykh chytan' pam'iati N. V. Paninoi [Phenomenon of Maidan at Ukrainian society: sociological interpritations. Materials of the International sociological readings in memory of N. Panina]. 2015. Pp. 15-32. [in Russian].

5. Prokhorova A. Metodolohichni osoblyvosti doslidzhennia osobystykh svidchen' uchasnykiv Majdanu 2013-2014 rokiv metodom napivstrukturovanoho interv'iu [Methodological fea- 
tures of the study of personal testimonies of Maidan (2013-2014) participants using the method of semi-structured interview]/ A. Prokhorova // Naukovi zapysky NaUKMA [Scientifi c notes NaUKMA]. 200. Sotsiolohichni nauky [Sociological studies]. 2017. [in Ukrainian]

6. Snow D. Frame Alignment Processes, Micromobilization, and Movement Participation / D. A. Snow // American Sociological Review. 4. 1986. Pp. 464-481.

7. Snow D., Benford R. Ideology, frame resonance, and participant mobilization / D. A. Snow, R. D. Benford // International social movement research. 1. 1988. Pp. 197-217.

8. Vid Majdanu-taboru do Majdanu-sichi: scho zminylosia? [From Maidan-camp to MaidanSich: what has been changed?] http://dif.org.ua/article/vid-maydanu-taboru-do-maydanusichi-shcho-zminilosya [in Ukrainian].

\title{
MOTIVES FOR PARTICIPATION OF INDIVIDUALS IN THE PROTEST EVENTS OF MAIDAN (2013-2014)
}

\author{
A. Prokhorova \\ National University of Kyiv-Mohyla Academy, \\ H. Skovoroda str. 2, Kyiv, 04655,Ukraine, \\ anna_prokhorova@ukr.net
}

The article studies the motivational framing of the protest events on the Kyiv Maidan (2013-2014) relying on the pool of 300 in-depth interviews collected during the fi rst six months after the events. The investigation of the oral testimonies of the active members of Maidan events made possible to identify the cognitive constructs and interpretations that underlie the motivational component of the framing of the social movement. The research of in-depth interviews allowed us not only to detect a wide range of motives that had encouraged the participants of the Maidan to collective actions but also to interpret these motives more correctly.

Motives for the participation of the respondents in the Maidan directly depended on the course of events. Changes in interpretations of the personal motives to take part in the social movement coincide in time with the main transformations of the framing of protest. The motives differed not only depending on which stage of events the person had decided to join the Maidan. The same person outlined his or her own reasons for participation in different ways on different stages of the Maidan. The main group of motives for participation at the fi rst stage of the protest was mostly related to the renovation of the political course of Ukraine towards Europe with its quality of life and respect for human rights and freedoms. Then after the police had cruelly beaten the protesters, participants started to join the movement mainly against excessive use of force by law-enforcement authorities, for the condemnation of those who had been guilty in the beating, for the resignation of the government and the president and because of other similar motives.

Motives for participating in the Maidan also differed depending on the roles of the activists. Such differences were especially visible during the periods of violent confrontation between the protesters and law-enforcement authorities. The motives of the individuals who were directly at the Maidan differed from the motives of those who were involved in 
organizing the Maidan's life or helping the victims. For the fi rst category of people the common motive was «If not me, then who else?» or the revenge motive. While for the second category more common motives were guilt, desire to help, desire to protect.

According to the research, at the beginning of the social movement the motives for the participation of activists were more specifi $\mathrm{c}$ and local. People were protesting against the new foreign policy of the country, for punishing those, who had been guilty of beating the protesters, and so on. On the other hand, speaking about later events, respondents more often referred to moral and psychological motives and stimuli for participation in the Maidan: conscience, guilt, desire to help, desire to protect etc.

So the motives and stimuli for taking part in the protest depended on the dynamics of events on Maidan and on the roles of individuals during the Revolution of Dignity.

Key words: Maidan, motivation, framing, in-depth interview. 